\title{
Enhancing Competitiveness of Wild Pigs Feeding and Wild Pork Processing During Evfta - A Case Study in Asian Countries: Vietnam, China and Thailand
}

\author{
Leng Thi Lan, Bui Thi Thom² and Dinh Tran Ngoc Huy ${ }^{2}$ \\ ${ }^{1}$ Thai Nguyen University of Agriculture and Forestry, Vietnam. \\ ${ }^{2}$ Banking University HCMC, Ho Chi Minh city, Vietnam - International \\ University of Japan, Japan \\ Corresponding author email: dtnhuy2010@gmail.com
}

\section{ABSTRACT}

Pork, especially wild pork meat is one of the delicious major foods in Asian meals, researches have been made to improve quality of feeding wild pigs and pork has been meaningful in recent years. China, Thailand and Vietnam are 3 countries in Asia where people set up high quality wild pg farming, hence this study will make a comparison among three nations. Authors mainly use statistics, research and qualitative analysis including synthesis and inductive methods. Feeding wild pigs in Vietnam environment in Northern region of Vietnam such as Thai Nguyen province, we need to combine nutrition food with protein, energy and acid amine at proper proportion. Next, from wild pork meat, we can process into delicious food offered to markets. Last but not least, we also make suggestions for exporting wild pork meat to world markets including not only US but also European under EVFTA agreement.

KEY WORDS: EXPORT, FEEDING, WILD PORK AND PIGS, VIETNAM, THAI NGUYEN, CHINA, THAILAND.

\section{INTRODUCTION}

As Bui Thi Thom, Dinh Tran Ngoc Huy (2021) stated that Vietnam can try to adapt to pork meat criteria with high quality from European markets in order to export wild pork to Europe in future during EVFTA. The door to the EU has opened wide when tariff barriers are removed according to the schedule. However, to be able to stand firmly in this market, Vietnamese goods still have to overcome a series of challenges such as: Rules of origin, requirements on traceability, technical standards, dynamic hygiene and safety, etc. opened wide when tariff barriers were removed according to the schedule.The EU is one of Vietnam's largest export markets.

Biosc Biotech Res Comm P-ISSN: 0974-6455 E-ISSN: 2321-4007

\section{crossef}

Identifiers and Pagination

Year: 2021 Vol: 14 No (7) Special Issue

Pages:240-246

This is an open access article under Creative

Commons License Attribn 4.0 Intl (CC-BY). DOI: $h t t p: / / d x$.doi.org/10.21786/bbrc/14.7.54
Ballari and Garcia (2013) also mentioned that Wild boar diet is dominated by plant material $(\varangle 90 \%)$ in both ranges, but animal matter and fungi are consumed in greater proportions in the introduced range than in the native range. Food items frequently include agricultural crops (especially in the native range) and endangered animal species (especially in the introduced range). Energy requirements, food availability, and seasonal and geographical variations are major factors influencing food selection by wild boar. These factors may also interact with human activities (e.g. agricultural crops, supplementary feeding) to influence diet composition further. Dietary studies should be more rigorous and consistent across ranges to allow better comparisons.

And Bui Thi Thom, Dinh Tran Ngoc Huy, Tran Van Phung (2021) also stated that Pig farming is very important in Vietnam, esp. In Thai Nguyen city and Northern provinces, pork products are suitable for people's taste. At present, most pig breeds are selected and raised in accordance with local conditions, especially wild boar and hybrids are very popular with people, the demand for products is increasing day by day.
Article Information

Received: $11^{\text {th }}$ May 2021

Accepted after revision: $18^{\text {th }}$ July 2021 
We structure study with introduction, literature review, method, main findings, discussion and conclusion. We also see in below figure feeding wild pigs.

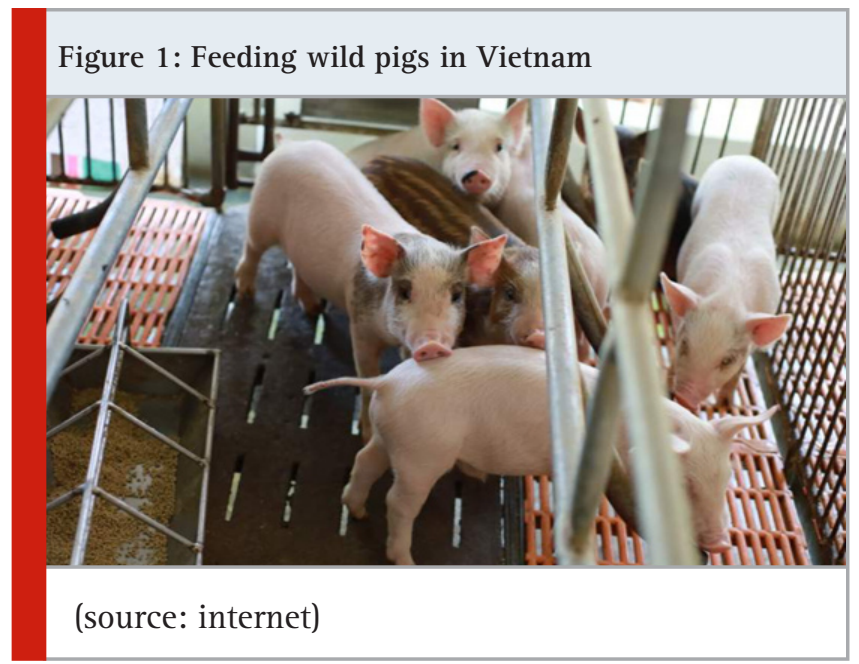

2. Literature Review: We summarize related studies in below table 1

\section{METHODOLOGY}

Authors also use statistic and data to make analysis an propose solutions. Experiences in Vietnam food processing (wild pork meat) also mentioned. Beside, Authors mainly use combination of quantitative methods and qualitative methods including synthesis, inductive and explanatory methods.

\section{RESULTS AND DISCUSSION}

4.1 Effect of nutritional composition in the diet: Dietary composition from a modern point of view is a general balance in terms of quantity and quality of nutrients such as proteins, amino acids, minerals, vitamins, starches, and fats with an appropriate ratio to ensure adequate nutrition. ensure high digestibility and feed utilization efficiency, in which the appropriate protein ratio will contribute to feed costs, reduce costs and improve productivity. In the balance relationship between nutritional components, people are most often interested in the protein/Exchange energy (energy) relationship; amino acids/energy, maximum fiber content.... The nutritional balance in the diet was developed for pig subjects and incorporated into the dietary standards.

Ideal protein concept: The ideal protein contains all the amino acids in the proportions required by pigs. Thus, all the essential amino acids and the sum of the nonessential amino acids in the ideal protein have the same role. In the ideal protein, the ratio of amino acids is based on the relationship to the amount of protein in the diet, where lysine is calculated as $100 \%$. For growing pigs this ratio is as follows: (According to ARC, 1981, Wang, 1990; Fuller,1979 , Cole 1992 , Chung 1992, 1998 ) and Campbell, 1985) Of these, cystine can account for up to
$50 \%$ of the requirements for sulfur-containing amino acids and tyrosine contains 50\% of the requirements for cyclic amino acids. Methionine and Pheniallanine can be converted to cysteine and tyrosine with 100\% activity. This conversion follows the ratio of 1.25 methionine = 1 cystine. Arginine is an essential amino acid only for young cattle when they are in strong growth, but when they are mature, the body can synthesize enough of their own needs. The ideal ratio of amino acids mentioned above is suitable for all types of growing pigs regardless of genetics, characteristics and weight. (source: Wild pigs project, Bui Thi Thom et al, 2013).

The role of protein and amino acids in meat-raising pigs: We already know that amino acids are the structural components of proteins. The various proteins of the muscles, bones, blood, organs and cells of the body have about 20 amino acids. Of which, 10 amino acids are essential amino acids, which are amino acids that must be provided from the feed for the pig to synthesize into the cell's protein. The remaining amino acids are non-essential amino acids, which the pig's body can synthesize from glucose, metabolites and other sources. On the other hand, since pigs are monogastric animals, they must rely on dietary amino acids to meet their essential amino acid requirements. Therefore, the protein in the diet must be easily digestible and the amount of amino acids released must meet the 10 essential amino acids. (source: Wild pigs project, Bui Thi Thom et al, 2013).

Hope (1958) mentioned that nutrition needs of pigs: A complete diet includes proteins, carbohydrates, fats, minerals and vitamins plus crude fibre and ample supplies of good water. The bulk of the pig's diet is made up of crushed grain which is rich in carbohydrates and has adequate fibre and phosphorous. An animal protein supplement and the calcium supplement detailed later, provide the supplementary protein fats, minerals and vitamins which are needed to build up the basic grain ration into an efficient production food. Proteins may be of animal or vegetable origin but supplies of animal protein are essential if pigs are to be reared successfully. Good sources of animal protein for pig-feeding are meatmeal, whalemeal, dried whale solubles and separated milk. Young green crops and pastures and leguminous plants such as peas and beans are the main sources of vegetable protein available in Australia. In general terms, the proteins are utilised in building up muscle, nerves, bone and blood.

Cole et al (1992) suggested that with different pig breeds, with different characteristics, body weight, or growth, there are different protein requirements, but in terms of quality ( amino acid composition) of that protein is not different. This conclusion is based on the fact that it is difficult to distinguish the structural patterns of amino acids of meat cell proteins of different weight types of pigs. This shows that, if we know the ratio of amino acids of this type of pig, it can be applied to other types of pigs, other breeds. 
Table 1. Previous studies

\begin{tabular}{|c|c|c|}
\hline Authors & $x \cos x$ & Comtent, results \\
\hline W.A. Teletnep & 1966 & $\begin{array}{l}\text { Feeding comditions, not only } \\
\text { affect the amount of } \\
\text { digestive juices secreted, but } \\
\text { also change the activity of } \\
\text { digestive } \\
\text { mankedly. }\end{array}$ \\
\hline \multirow[t]{2}{*}{ Phung Thang Tong et al } & 20104 & 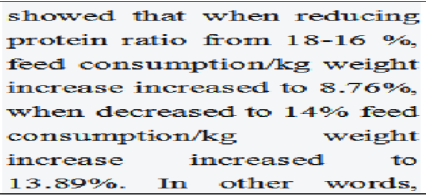 \\
\hline & & $\begin{array}{l}\text { When increasing the protein } \\
\text { level of the diet, there was } \\
\text { an effect of reducing feed } \\
\text { consumption/kg weight gain } \\
\text { of pigs, which is relatively } \\
\text { consistemt } \\
\text { experimental results when } \\
\text { studying pigs. hisbrid forest. }\end{array}$ \\
\hline Dao Le IIang & 20108 & $\begin{array}{l}\text { Widl boars are more active } \\
\text { at night, at dusk and at } \\
\text { dawn. when the pigs } \\
\text { matures it will leawe the } \\
\text { herd and live indlependently } \\
\text { around so-3 so kg, with } \\
\text { some domesticated pigs up } \\
\text { to } 450 \mathrm{~kg} \text {. Malles are usidally } \\
\text { larger than females. }\end{array}$ \\
\hline Ton That sonet al & 20106 & 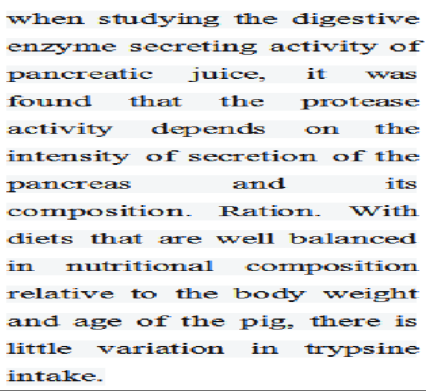 \\
\hline $\begin{array}{l}\text { Homing Tozm Thang Cao } \\
\text { Wan }\end{array}$ & 2006 & $\begin{array}{l}\text { when studying the effect of } \\
\text { the same level of protein om } \\
\text { the nitrogen digestion in the } \\
\text { small intestine of pigs, it } \\
\text { was found that, in the diet, } \\
\text { there are different types of } \\
\text { feeds. different diets, the } \\
\text { content of nitrogen forms in } \\
\text { the intestimal chyme is } \\
\text { different. }\end{array}$ \\
\hline Thanapongtharm & 2016 & 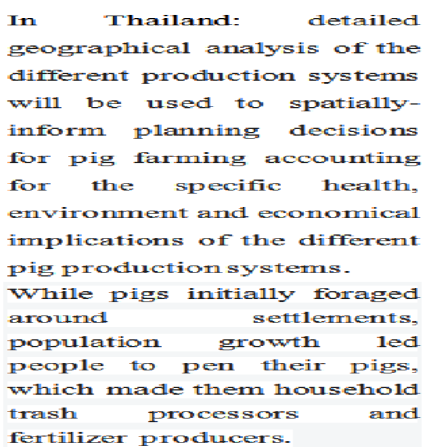 \\
\hline $\begin{array}{l}\text { Bui Thi Thom, Dimih Tran } \\
\text { Ngoc Huy, Tran Wan Phumg }\end{array}$ & 2021 & $\begin{array}{l}\text { stated that Willd boar } \\
\text { laybricls meat has a rich and } \\
\text { higher nutrient content than } \\
\text { domestic pork, helping us to } \\
\text { compensate for } \\
\text { vitamins that vegetables and }\end{array}$ \\
\hline & & $\begin{array}{l}\text { fruits do not have or have } \\
\text { very little, such as vitamins } \\
\text { B1, BZ, B6, B.12, } \\
\text { A and } D \text {. }\end{array}$ \\
\hline
\end{tabular}


Another problem, if dietary protein is lacking, one or more of the essential amino acids, protein accumulation is only improved by the addition of these amino acids. If dietary protein is lacking in non-essential amino acids, protein accumulation will be improved by the addition of any amino acids. Therefore, we can interpret the ideal protein as one that will not be improved by the addition of any additional amino acids. And only when all amino acids are added at the same time, the process of protein accumulation is improved.

Pig protein requirements: In a nutshell, the maintenance requirement is the amount of protein that replaces the proteins that are required to be lost from the body consisting mainly of skin proteins and various nitrogen metabolism end products in the urine. Forced losses are generally assessed by determining nitrogen excretion when fed a protein-free diet and have a normal relationship to body mass. Whether or not this estimate is applicable, to animals fed diets with normal levels of protein in the feed. (source: Wild pigs project, Bui Thi Thom et al, 2013).

\begin{tabular}{|l|c|c|c|}
\hline ysine & 100 & Isoleucine & 50 \\
\hline Threonine & 65 & Leucine & 100 \\
\hline Methionine + Cystein & 55 & Histidine & 33 \\
\hline Tryptophan & 19 & $\begin{array}{c}\text { Phenylalanine } \\
\text { + Tyrosine }\end{array}$ & 100 \\
\hline Arginine & 42 & Valine & 70 \\
\hline
\end{tabular}

Interaction relationship between protein and metabolic energy: Changes in the content of some amino acids in the internal organs can be attributed to the energy and protein intake that affect blood and organ mass (Bikker et al. 1994) and related fractions increased with increasing energy intake.The mass of blood, kidney, pancreas and spleen also increased with increased protein intake Schulz and Oslage (1976) (Excerpt from Vu Duy Giang 1999 ) , protein content in blood, digestive system and liver accounts for 5, 4 and 3\% respectively compared with whole body protein. When different levels of energy intake will greatly affect the content and composition of acids The content of lysine, threonine, histidine, tyrosine, aspartic acid and serine in the internal organs was 10 30\% higher, while cystine, leucine, phenylalanine valine was 40 - 50\% higher than that in the carcass and the organs. The content of methionine, arginine, isoleucine, glutamic acid and glycine in the carcass was $10-30 \%$ lower than that of the organ.

The role of food exchange energy in the survival of pigs: All living, developing and reproductive activities of pigs are associated with the process of using and exchanging energy. Energy in food is stored in the physical forms of food such as fat, sugar, protein, and carbohydrates. Pigs receive food energy from the outside, through digestion, absorption in the digestive tract into the body and synthesized into fat, glucose, and pure protein of the pig's body. (source: Wild pigs project, Bui Thi Thom et al, 2013). Energy participates in the construction of nerve cells, nerve sheaths, forming important compounds such as lipoproteit, glucoproteit found in nerve cell membrane tissue, in exocrine glands. Fat both stores energy and acts as a cushion under the skin, surrounding the digestive tract, circulation, and respiration to resist mechanical impact, heat and cold for the body. Pigs need more energy than other cattle because the genetic makeup of pigs accumulates fat about 45-50\% (Le Hong Man et al., 2003).

The difference is not statistically significant $(\mathrm{P}>0.05)$. The results of Table 1 show that in the experimental groups, with the same results of the experimental pigs, but the lean percentage in the experimental groups TN 1 has a higher percentage of lean meat, but the difference is not significant. significant, not statistically significant ( $P$ $>0.05$ ). The results of chemical composition analysis of experimental pork Table 1 also show that there is almost no difference in the proportion of chemical components of meat, especially the protein ratio of pork. (source: Wild pigs project, Bui Thi Thom et al, 2013)

\begin{tabular}{|c|c|c|c|c|}
\hline No & Description & Unit & Lot TN1 $(n=3)$ & Lot TN2 $(n=3)$ \\
\hline 1 & Live weight & $\mathrm{Kg}$ & $24,11 \pm 2,45$ & $24,14 \pm 2,16$ \\
\hline 2 & Jaw hook ratio & $\mathrm{Kg}$ & $78,12 \pm 0,19$ & $78,89 \pm 0,43$ \\
\hline 3 & Sliced meat & $\mathrm{Kg}$ & $13,45 \pm 2,10$ & $13,88 \pm 2,15$ \\
\hline 4 & Ratio of carcass & $\%$ & $68,59 \pm 1,26$ & $68,69 \pm 2,09$ \\
\hline 5 & Lean meat ratio & $\%$ & $55,67 a \pm 0,81$ & $55,23 a \pm 1,11$ \\
\hline 6 & Fat meat ratio & $\%$ & $14,07 \pm 0,76$ & $14,23 \pm 0,45$ \\
\hline
\end{tabular}

4.3 Thailand, China wild pigs compared to Vietnam wild pigs: We compare in below table:

The Vietnamese wild boar lives a lot in different ecological regions of which the types of wild boar in the Southeast, North and Laos may be one. In the old days in Da Lat, wild boar had two types, one with little hair, usually found at an altitude of $1,000 \mathrm{~m}$, and one on both cheeks with white lines, weighing $150 \mathrm{~kg}$ or more. Currently, this pig breed is being domesticated and 
bred for livestock production and they usually have two groups of breeds: Long-faced breed group and shortfaced breed group, so far, according to origin, there are four types of wild boar raised. Northern Vietnamese wild boar raised in $\mathrm{Ba} \mathrm{Vi}$, HanoiPhu Yen wild boar raised at Hoa Khanh rare animal farm, Khanh Hoa Cat Tien wild boar raised on farms in Can Giuoc, Long An and Dong Nai Binh Phuoc wild boar in the Southeast region (source: wikipedia.com, access date 12/7/2021).

Table 3. Comparison of wild pigs

\begin{tabular}{|c|c|c|}
\hline Thailand wild pigs & Vietnam wild pigs & China wild pigs \\
\hline $\begin{array}{l}\text { Thai wild Boar is a breed of } \\
\text { wild boar imported from } \\
\text { Thailand to Vietnam, } \\
\text { through many breeding and } \\
\text { breeding processes, this wild } \\
\text { boar has become quite } \\
\text { popular in the market today, } \\
\text { especially in the North, } \\
\text { many models The breeding } \\
\text { model and the whole market } \\
\text { are very fond of this wild } \\
\text { boar. }\end{array}$ & $\begin{array}{l}\text { The Vietnamese wild boar is } \\
\text { an indigenous breed of wild } \\
\text { boar in Vietnam, living in } \\
\text { many forests in Vietnam, } \\
\text { some centers are allowed by } \\
\text { the state to catch from the } \\
\text { wild to breed but very few, } \\
\text { most are hunters catch and } \\
\text { sell them to breeders to } \\
\text { breed themselves and sell to } \\
\text { the market. Vietnam Wild } \\
\text { Boar has many beautiful and } \\
\text { popular lines today such as } \\
\text { Binh Phuoc Wild Boar, } \\
\text { Tanh Linh Binh Thuan Wild } \\
\text { Boar, and Nam Wild Boar. } \\
\text { Cat Tien, Central Highlands } \\
\text { Wild Boar, Song Pha Ninh } \\
\text { Thuan Wild Boar (the wild } \\
\text { boar caught in the forest, } \\
\text { give it that name) ... each } \\
\text { line has its own set of points } \\
\text { and beauty. Vietnam's wild } \\
\text { boar is now favored by } \\
\text { many customers. preferred, } \\
\text { especially in the Central and } \\
\text { Southern regions }\end{array}$ & $\begin{array}{l}\text { The Chinese wild boar or } \\
\text { North China wild boar } \\
\text { (Scientific name: Sus scrofa } \\
\text { moupinensis) is a subspecies } \\
\text { of wild boar found in } \\
\text { Vietnam, Sichuan, and } \\
\text { China coast. Currently there } \\
\text { are many records of only the } \\
\text { diversity of pigs in this } \\
\text { subspecies, this diversity is } \\
\text { not recognized at present but } \\
\text { it is possible that these } \\
\text { diverse groups may be a } \\
\text { separate subspecies. }\end{array}$ \\
\hline
\end{tabular}

4.4 Wild pork meat processing: Bui Thi Thom, Dinh Tran Ngoc Huy (2021) mentioned that the EVFTA Agreement can increase the price competitiveness of Vietnamese goods when imported to this important market. Breeding wild boar is becoming a rich trend among young people who are passionate about clean animal husbandry. This is not just a simple hybrid wild boar breeding technique, but it is a problem that needs answers from young people about the technique of raising wild boars in a wild hybrid.

Today, the need to eat clean and drink clean of Vietnamese people is being concerned by many people. Initially just eating clean vegetables, clean fruits and now we have gradually switched from normal white pork to natural wild boar. Although the price is somewhat higher, but because of the quality and nutritional composition that it brings, they are still preferred by housewives. Hope (1980) said correct feeding helps pigs to grow quickly and to develop carcasses containing fat and lean meat in the proportions which the bacon-curers and the consumers of pig meats find most acceptable. Huy et al (2015) have mentioned important roles of banks in financing economic activities including agriculture. 
Figure 2: Wild pigs in North of China

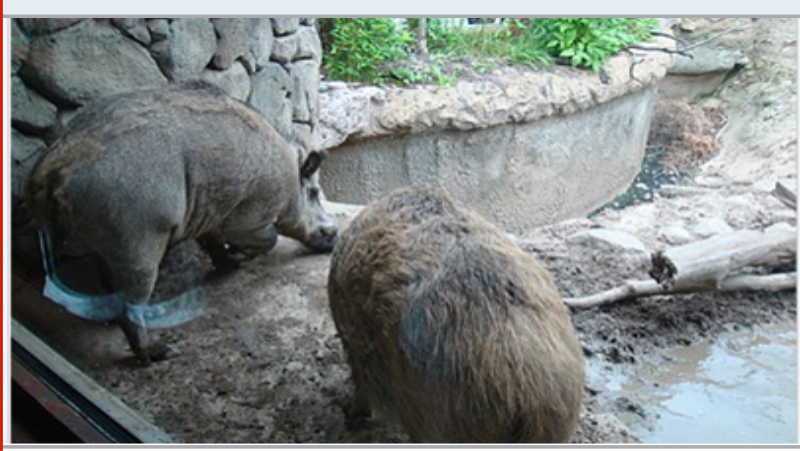

(source: internet)

Figure 3: Several wild pigs in the world

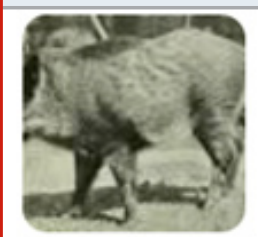
algira
Sus scrofa

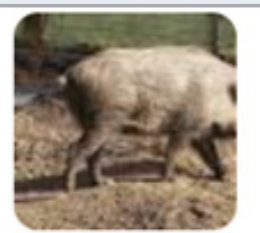

Sus scrofa libycus

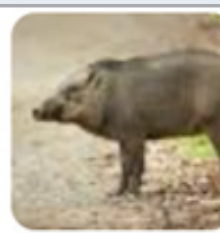

Sus scrofa vittatus
Bui Thi Thom, Dinh Tran Ngoc Huy (2021) mentioned that Feeding wild pigs and managing wild pork meat quality is meaningful in Vietnam, esp. In Thai Nguyen province as pork products can offer variety of tastes due to food processing and suitable for Vietnamese tastes and can export to the world widely. At present, most pig breeds are selected and raised in accordance with local conditions, especially wild boar and hybrids are very popular with people, the demand for products is increasing day by day. But raising pigs is also facing many obstacles, because wild boars are wild, domesticated more difficult than foreign pigs, and require a large area of land and a rich source of green food. Wild boars have good characteristics of adaptability, tolerance to harsh conditions in mountainous areas, taking advantage of natural food sources and low technical requirements.

\section{CONCLUSION}

Under the conditions of Thai Nguyen, the raising of wild boar and hybrids is also being concerned by people, but the system is gradually giving initial results on domestication, behavior monitoring... as for work. For research on diet and nutrition, we are conducting experiments. Therefore, the synchronous research from the domestication of breeding stock, cross-breeding, rations, care and rearing of wild boars and hybrids is an issue that needs to be completed in the coming time.

Limitation of research: We need to propose solutions for wild pork to enter European and world markets

\section{REFERENCES}

Ballari, S.A. and Barrios-García, M.N., 2014. A review of wild boar S us scrofa diet and factors affecting food selection in native and introduced ranges. Mammal Review, 44(2), pp.124-134.

Fuller, M.F., Livingstone, R.M. and Baird, B.A., 1979. The optimal amino acid supplementation of barley for the growing pig: 1. Response of nitrogen metabolism to progressive supplementation. British Journal of Nutrition, 41(2), pp.321-331.

Hang, T.T.B., Nhung, D.T.H., Huy, D.T.N., Hung, N.M. and Pham, M.D., 2020. Where Beta is going-case of Viet Nam hotel, airlines and tourism company groups after the low inflation period. Entrepreneurship and Sustainability Issues, 7(3), p.2282.

Hoang Toan Thang, Cao Van 2006, Textbook of animal physiology, Agricultural Publishing House, 57-70.

Hope, K.M., 1958. Profitable pig-feeding-The importance of protien. Journal of the Department of Agriculture, Western Australia, Series 3, 7(3), pp.269-280.

Huy, D.T.N., Thach, N.N., Chuyen, B.M., Nhung, P.T.H., Tran, D.T. and Tran, T.A., 2021. Enhancing risk management culture for sustainable growth of Asia commercial bank-ACB in Vietnam under mixed effects of macro factors. Entrepreneurship and Sustainability Issues, 8(3), p.291.

Huy, D.T.N., Loan, B.T.T. and Pham, T.A., 2020. Impact of selected factors on stock price: a case study of Vietcombank in Vietnam. Entrepreneurship and Sustainability Issues, 7(4), p.2715.

Huy, D.T.N., 2015. THE CRITICAL ANALYSIS OF LIMITED SOUTH ASIAN CORPORATE GOVERNANCE STANDARDS AFTER FINANCIAL CRISIS. International Journal for Quality Research, 9(4).

Huy, D.T.N., Dat, P.M. and Anh, P.T., 2020. BUILDING AN ECONOMETRIC MODEL OF SELECTED FACTORS'IMPACT ON STOCK PRICE: A CASE STUDY. Journal of Security Ct Sustainability Issues, 9.

Huy, D.T.N. and Hien, D.T.N., 2010. The backbone of European corporate governance standards after financial crisis, corporate scandals and manipulation. Economic and Business Review, 12(4), pp.215-240.

Kvisna, Keosua, Phia Kraixeng Xrium - Thailan, 2005. Technical process of breeding and developing wild boar, Translation by Le Van Hien and Le Tuan Tu.

Phung, T.V., Hien, T.Q., Van, T.T., and Hao, H.T., 2004. Textbook of pig breeding (University). Agriculture Publishing House, Hanoi, 16-25; 113-115.

Phùng Thang Long 2004, “Anh hurng caa các thurc An protein khác nhau trong khau phan den kha nang ssn xuat và san pham thit xe cua lon lai (Landrace $\mathrm{x}$ Yorkshire) x Yorkshire”, Tap chí Nông nghiep và phát 
trien nông thôn, so (1), tr. 52-53.

Thi Hang, N., Thi Tinh, D., Ngoc Huy, D.T. and Hong Nhung, P.T., 2021. Educating and training labor force Under Covid 19; Impacts to Meet Market Demand in Vietnam during Globalization and Integration Era.

Thom, B.T. and Huy, D.T.N., 2021. Study on Wild Pork and Pigs in Thai Nguyen, Vietnam-and Pork Meat Export Criteria to Europe. REVISTA GEINTEC-GESTAO INOVACAO E TECNOLOGIAS, 11(4), pp.51-65.

Todorov, N.A., Girginov, D.G., Eggum, B.O., Boisen, S., Børsting, C., Danfær, A. and Hvelplund, T., 1991. Protein Metabolism and Nutrition. Proceedings of the 6th International Symposium on Protein Metabolism and Nutrition, EAAP-Publication No 59, Volume 2.
Tran Van Phùng, Tu Quang Hien, Trin Thanh Vân, Hà Thi Hao 2004, Giáo trình chan nuôi lin (He Đai hoc), Nhà xuat ban Nông nghiep, Hà Noi, tr. 16-25; 113-115. Vietnam Standard 2007, Animal feed, Method of determining crude fiber content, TCVN 4329 - 2007.

Vietnam Standard 2001, Animal feed, Methods of determining phosphorus content, TCVN 1525: 2001 (ISO 6491:1998), p. 140 - 142.

Vietnam Standard 2002, pH measurement method, TCVN 4835: 2002 (ISO 2917: 1999).

Vo Van Su, Tang Xuan Luu 2008, "Initial results of pure Thai wild boar farming in Ba Vi and Bac Giang", Scientific report, National Institute of Livestock Production, Hanoi, 2008. 